\title{
The Innovation of MOOC Based E-Marketing to Improve Entrepreneurship Administration Management for Vocational Education Students in Industrial Revolution 4.0 Era
}

\author{
Andika Bagus Nur Rahma Putra*), Amat Mukhadis, Tuwoso, Nurul Ulfatin, Surjani \\ Wonorahardjo, Habiddin, Made Duananda Kartika Degeng \\ Universitas Negeri Malang \\ Tee Tze Kiong \\ Universiti Tun Hussein Onn Malaysia \\ *)E-mail address: andika.bagus.ft@um.ac.id
}

\begin{abstract}
This research has aims to: (1) develop MOOCs based e-marketing; (2) testing the attractiveness of MOOCs based e-marketing; and (3) knowing the level of effectiveness of MOOCs based e-marketing. The method in this study is research and development. The results of this study include: (1) the results of the e-marketing expert test and website marketing design expert test have a percentage: $81.50 \%$ (ease of accessing consumers), $84.10 \%$ (presentation of goods/services sold), $79.10 \%$ variation of website content), $86.00 \%$ (compatibility with website goals), $83.70 \%$ (harmony of each page of views), $83.70 \%$ (complete description of products sold), $83.70 \%$ (attractiveness of e-website marketing), $85.00 \%$ (ease of order process for consumers), $81.50 \%$ (responsible admin e-marketing), $81.50 \%$ (trouble shooting website problems); (2) MOOCs based e-marketing proved effective in improving the management of student entrepreneurship administration in the vocational sector in the Industrial Revolution 4.0 era, indicated by the results of the final ability test which showed significant differences between control classes without using e-marketing based MOOCs and experimental classes using MOOCs based e-marketing; and (3) E-marketing based MOOCs needs to be further developed because it can improve the management of entrepreneurial administration in vocational students in the Industrial Revolution era 4.0.
\end{abstract}

Keywords: MOOCs, management administration, entrepreneurship, vocational education, industrial revolution 4 .

The acceleration of the development of communication, media and informatics technology has changed the community in all its activities (Karim, 2016; Turner \& Gianiodis, 2018). This has an impact on companies that are required to have a strong business strategy. The strategy is to improve service to customers and develop marketing. In building these strengths and strategies, tools are needed that can support marketing in increasing product and service sales (Putra, Irdianto, \& Mukhadis, 2016), (Arbaugh, Fornaciari, \& Hwang, 2016). The flow of information circulation in the business world is very fast and even has become an urgent interest. Technology also developed in it so that it became a term that we are familiar with information technology (Putra et al., 2018), (Chawla, Chanda, Angra, \& Chawla, 2018).
However, this is still a major problem if the company is not able to train its employees to know the digital world. The development of information technology will facilitate companies in running their business (Alshanbari \& Issa, 2014; Imgrund, Fischer, Janiesch, \& Winkelmann, 2018). Currently, the development of the internet is happening very fast and can reach the whole world, and every company wants its products to be known by the wider community.

One information and communication technology that can be used is the internet. The use of the internet can easily communicate and obtain the information needed quickly and accurately (Mackay \& Zundel, 2017; Rahimi, Møller, \& Hvam, 2016). Also, companies can market their products 
electronically or online. This is termed e-marketing. E-marketing encourages companies to be able to promote their existence to be better known in the wider community. E-marketing is very interesting because in the era of globalization (industrial revolution 4.0) it demands a lot of convenience and speed of information (Fornaciari et al., 2017; Recker \& Mendling, 2016). For companies, e-marketing can expand the market, expand the company's brand image, and provide convenience in providing information to its customers. Whereas for customers, the desired goods/services can be obtained without having to leave the house/office (making it easier for customers to access company product information), simply by opening a website, choosing the desired product/service, ordering, making transactions and products/services. The choice of an e-marketing strategy that matches the company and knows the details of the ways and effects of its application is very important and needed by the company.

E-marketing is defined as a process of building and maintaining relationships with customers through an online activity to provide facilities for exchanging ideas, products and services to fulfill the wishes of both parties (Irdianto \& Putra, 2016; Mukhadis, Putra, Nidhom, Dardiri, \& Suswanto, 2018). Also, e-marketing is the marketing side of e-commerce which consists of business enterprises to provide information, promote and sell products and services through the internet. Other parts besides e-marketing can be in the form of e-purchasing, which is the side of the ecommerce sales process (Malinova \& Mendling, 2018), (Andrade, Chopra, Nurlybayev, \& Golab, 2010). Today, the digital or internet world is also enlivened by the presence of a system called MOOCs. Massively Online Open Courses (MOOC) is one of the online technology transformation transformations. MOOC is also often associated with one of the evolutions of e-learning so that not a few who use it as an alternative to learning something new (Bozkurt, Akgün-Özbek, \& Zawacki-Richter, 2017; Wu \& Chen, 2017).

Regarding its implementation to support formal learning, it can be said that its utilization is not optimal. This is because there are those who think that the results are very efficient, but some consider it inefficient. Some overseas schools and universities seriously utilize the MOOC model for learning, some of which even fully use related services for learning (Hew, Qiao, \& Tang, 2018; Pardos, Tang, Davis, \& Le, 2017). The trend of elearning in Indonesia itself can be said to be still in a transitional period, right now it is precisely the business people who are observed are interested in exploring its benefits for the development of human resources in their environment. Whereas for consumers, it does not yet look significant. Perhaps there are still many factors that need to be addressed and adjusted, especially related to infrastructure and culture.

About e-marketing, MOOCs can help emarketing development by providing many additional features. For example by using MOOCs technology, e-marketing networks can be used to conduct market research and product development, develop a strategy and tactics to persuade customers to buy, provide online distribution, maintain customer records, lead customer satisfaction services, and collect feeds back from customers so that the results can continue to be improved and the process is more efficient and effective (Huisman, Admiraal, Pilli, van de Ven, \& Saab, 2018; Lambert \& Alony, 2015; Zancanaro, Nunes, \& Domingues, 2017). The purpose of E-marketing based MOOCs is to combine various information technologies to change marketing strategies to increase customer value through segmentation; creating changes to satisfy consumers; improve planning and finalize concepts to facilitate promotion and so forth. At present, there are very few entrepreneurs in Indonesia who utilize E-marketing based MOOCs. That is because the facilities and infrastructure that have not fully supported. What's more about the geographical location of the business. Internet network problems, the ability to process emarketing websites, to the management of entrepreneurial administration that is relatively not strong. In fact, at every level of education (especially vocational education) an understanding of the entrepreneurial spirit has been instilled deeply (Irdianto \& Putra, 2016; Putra, Mukhadis, \& Suhartadi, 2016).

Some researchers explain that the weak absorption of entrepreneurs in Indonesia is due to the cultivation of the entrepreneurial spirit when taking the education level is only focused on basic 
materials. There are still few educational institutions (vocational fields) that teach direct implementation of entrepreneurship. Such implementations include creating e-marketing websites, managing corporate administration, communicating with investors, and others. Based on quite several problems that have been described, it is very necessary to develop Emarketing based MOOCs technology to improve entrepreneurial administration management in vocational education students.

Electronic marketing (e-marketing) is a process of using information technology in the process of creating, communicating, and providing value to customers (Fox, Pittaway, \& Uzuegbunam, 2018; Gedeon, 2017). E-marketing affects traditional marketing in two ways. E-marketing is dominated by the results of information technology that is applied to traditional marketing (Abdullah, Sarfraz, \& Kazmi, 2018; Omeno \& Sang, 2018). Functionally, the e-marketing goal is divided into two. Currently, e-marketing is defined as a form of the process (Mukhadis et al., 2018; Putra, Irdianto, et al., 2016). So that electronic marketing, all activities are online or electronically based mechanisms that facilitate the manufacturing process of goods and services by manufacturers to satisfy customers. Electronic marketing utilizes network technology to coordinate market share research. Also, e-marketing also helps product development, develops strategies and tactics to lure customers, provide online distribution, maintain customer records. In the 4.0 Industrial Revolution era, e-marketing had a positive impact in creating customer satisfaction and collecting customer feedback (Saggaf, Salam, Wirawan, \& Hasanuddin, 2018; Strekalova, Karimipour, James, \& Treise, 2018). Electronic marketing promotes marketing programs that support the goals of companies implementing e-commerce. Elements of strategy in E-marketing planning explain how E-marketing objectives will be achieved.

Administrative management is defined as a process or framework that involves the process of directing, supervising and mobilizing the ability to carry out an activity in an organization (Arbaugh et al., 2016; Mackay \& Zundel, 2017; Torabi, Giahi, \& Sahebjamnia, 2016). Some experts explain that administrative management serves as the main control on human intelligence to analyze, plan, motivate, assess and supervise the effective use of human resources and materials used to achieve certain goals. Thus it can be concluded that management is a way to control or organize (organizing), preparation of personnel or staffing, direction and leadership, and control, to achieve the ultimate goal (Kolk \& Rivera-Santos, 2018), (Sousa $\&$ Rocha, 2018). In a role, the administrative management function is that the implementation of business is planned systematically and can be evaluated correctly, accurately, and completely to achieve the objectives productively, quality, effectively and efficiently. That is the most important part of the success of a business. The success of a business, one of which is influenced by the amount of entrepreneurial spirit that someone has. The concept of Entrepreneur includes organizing, managing, and assuming the risk of the business. The word entrepreneur is related to business activities or business activities in general (Coccia, 2017; Ferasso, Pinheiro, \& Schröeder, 2017). Entrepreneurs should be someone who can assess business opportunities (business) and combine various kinds of resources (resources) needed to take appropriate action to gain profit in the future. Entrepreneurship is essentially defined as a trait, character and character of someone who can creatively create innovative ideas into the real world

\section{METHOD}

The method used in this study is research and development methods. The initial stage of this research is to develop MOOCs based e-marketing. The product development results are then analyzed and tested for effectiveness. The stages and mechanism of product development in this study include data collection, research planning, product design development, field trials, revision of results, product feasibility testing, and final product revision process. The method mechanism in this study is gradually shown in Figure 1. 


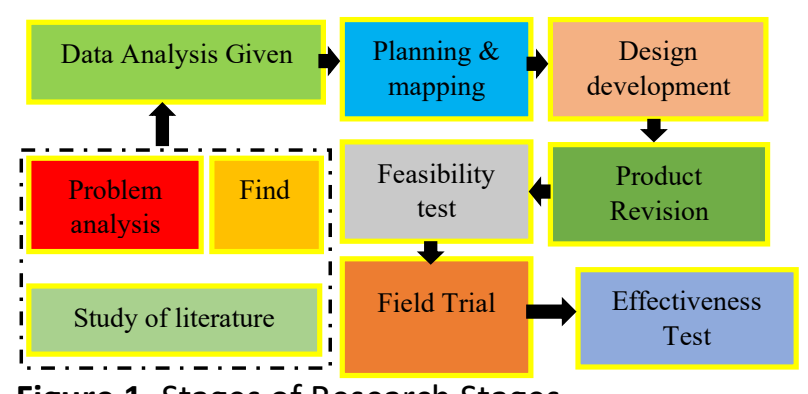

Figure 1. Stages of Research Stages

In the effectiveness test phase, the research instrument is through questionnaires in the form of questionnaires and test questions. In this test phase two classes were used, each of which was 29 students in the vocational field. Data analysis with e-marketing expert test, website design expert, attractiveness test, and t-testResearch method contains research designs, approaches used, development of instruments, data collection techniques, data analysis, and other processes deemed necessary. The research procedure is written in a straightforward and clear manner.

\section{RESULTS AND DISCUSSION}

The results of this study include two things, namely the development (product) in the form of emarketing based MOOCs and the effectiveness test of E-marketing based MOOCs in improving the management of entrepreneurship administration in vocational students in the Industrial Revolution 4.0 era. In the product development stage, an emarketing expert and website marketing design validation test was conducted. This test was carried out by four expert experts. Furthermore, the average value of each expert is calculated. Test results for emarketing experts and website marketing design are shown in Table 1.

Table 1. E-marketing Expert Test Results

\begin{tabular}{lll}
\hline Model Aspects & $\begin{array}{l}\text { Validity } \\
\text { Level (\%) }\end{array}$ & Decision \\
\hline $\begin{array}{l}\text { The ease of accessing } \\
\text { consumers }\end{array}$ & 81,50 & VTR \\
\hline $\begin{array}{l}\text { Presentation of } \\
\text { goods/services sold }\end{array}$ & 84,10 & VTR \\
\hline $\begin{array}{l}\text { Variations in website } \\
\text { content }\end{array}$ & 79,10 & VTR \\
\hline
\end{tabular}

\begin{tabular}{lcc}
\hline $\begin{array}{l}\text { Conformity with the purpose } \\
\text { of the website }\end{array}$ & 86,00 & VTR \\
\hline $\begin{array}{l}\text { Harmony on each page of } \\
\text { the display }\end{array}$ & 83,70 & VTR \\
\hline $\begin{array}{l}\text { Complete description of } \\
\text { products sold }\end{array}$ & 83,70 & VTR \\
\hline $\begin{array}{l}\text { The attraction of e- } \\
\text { marketing websites }\end{array}$ & 83,70 & VTR \\
\hline
\end{tabular}

\begin{tabular}{lcc}
\hline $\begin{array}{l}\text { Ease of order processing for } \\
\text { consumers }\end{array}$ & 85,00 & VTR \\
\hline $\begin{array}{l}\text { Responsible e-marketing } \\
\text { admin }\end{array}$ & 81,50 & VTR \\
\hline $\begin{array}{l}\text { Troubleshooting website } \\
\text { problems }\end{array}$ & 81,50 & VTR \\
\hline
\end{tabular}

$*$ VTR $=$ Valid without revision

In Table 1, it is explained that the validation test of e-marketing experts. This test is carried out by four e-marketing experts who have a value above $75 \%$. In the convenience aspect, consumers access, have a validity level of $81.50 \%$. In the aspect of serving goods/services sold, the validity level is $84.10 \%$. In the aspect of website content variation, has a validity level of $79.10 \%$. In the aspect of Conformity with the purpose of the website, it has a validity level of $86.00 \%$. In the Harmony aspect of each page, it has a validity level of $83.70 \%$. In the Completeness aspect, the description of the products sold has a validity level of $83.70 \%$.

In the Attractiveness aspect of e-marketing website, it has a validity level of $83.70 \%$. In the aspect of ease of order process for consumers, has a validity level of $85.00 \%$. In the Responsible aspect of e-marketing admin, it has a validity level of $81.50 \%$. In the aspect of Troubleshooting the website problem, has a validity level of $81.50 \%$. This means that all aspects of the E-marketing based MOOCs products have valid values without revisions. Furthermore, the test results of website marketing design experts were carried out by two expert experts. The test results are presented in Table 2. 
Table 2. Test results for website marketing design experts

\begin{tabular}{lcl}
\hline Indikator & Skor & Kategori \\
\hline Look neat and systematic & 5 & Very good \\
\hline $\begin{array}{l}\text { Display content section } \\
\text { layout }\end{array}$ & 4 & Good \\
\hline $\begin{array}{l}\text { Display material section } \\
\text { layout }\end{array}$ & 4 & Good \\
\hline $\begin{array}{l}\text { Selection of color } \\
\text { proportions }\end{array}$ & 4 & Good \\
\hline $\begin{array}{l}\text { Selection of fonts } \\
\text { Font size selection }\end{array}$ & 4 & Good \\
\hline $\begin{array}{l}\text { Display and animation } \\
\text { presentation }\end{array}$ & 5 & Very good \\
\hline $\begin{array}{l}\text { Selection of supporting } \\
\text { images }\end{array}$ & 4 & Good \\
\hline Website homepage & 4 & Good \\
\hline
\end{tabular}

In Table 2, it is explained that the nine indicators tested produce good and very good values. This shows that the product developed has a relatively good category level. The score shows that the Display indicator is neat and systematic, the products that have been developed are categorized as very good. On the display indicator of the content section, the products that have been developed are categorized as good. On the indicator display content section layout, products that have been developed are included in the good category. On the Display indicator of the material section layout, the products that have been developed are categorized as good. In the color proportion selection indicator, the products that have been developed are categorized as good. In the font selection indicator, the products that have been developed are categorized as good. In the letter size selection indicator, the products that have been developed are in the very good category. In the animation display and presentation indicator, the products that have been developed are in the very good category. In the supporting image selection indicator, the products that have been developed are categorized as good. On the homepage indicator, the products that have been developed are categorized as good.
The next step is to test the effectiveness of the product. At this stage it is carried out with a quasi-experimental process, which looks at the ability of students before and after using emarketing based MOOCs. Test questions from the entrepreneurship subject. Instruments using pre-test and post-test questions. Furthermore, the data were analyzed by t-test. The results of the t-test analysis of students' abilities before using MOOCs based emarketing are shown in Table 3.

Table 3. Summary of Initial Ability Test Results

\begin{tabular}{lllll}
\hline \multicolumn{5}{l}{ t-test for Equality of Means } \\
\hline $\mathrm{T}$ & Df & Sig. & $\begin{array}{l}\text { Mean } \\
\text { Difference }\end{array}$ & $\begin{array}{l}\text { Std. Error } \\
\text { Difference }\end{array}$ \\
\hline-1.11 & 57 & .28 & -1.85 & 1.68 \\
-1.10 & 54.38 & .28 & -1.85 & 1.68 \\
\hline
\end{tabular}

Table 3 presents the results of the initial ability test of control class students and experimental class before using E-marketing based MOOCs that has been developed. Summary of these results explains that $t$ count is 1.11 with the sig. 0.28. So that, it can be interpreted between the control class and the experimental class there is no significant difference. Furthermore, the results of the final ability test are presented in Table 4.

Table 4. Summary of Final Ability Results

\begin{tabular}{lllll}
\hline \multicolumn{5}{l}{ t-test for Equality of Means } \\
\hline $\mathrm{T}$ & Df & Sig. & $\begin{array}{l}\text { Mean } \\
\text { Difference }\end{array}$ & $\begin{array}{l}\text { Std. Error } \\
\text { Difference }\end{array}$ \\
\hline 7.63 & 57 & .000 & 11.98 & 1.57 \\
7.60 & 53.18 & .000 & 11.98 & 1.58 \\
\hline
\end{tabular}

Table 4. presented the results of the final ability test of students in the control class and experimental class. The control class does not use Emarketing based MOOCs, while the experimental class uses e-marketing based MOOCs. A summary of the results of the t-test shows that the significant value is 0.00 (sig. 0.00). So, it can be interpreted that there are significant differences between the results of the final control class ability test and the final ability of the experimental class. 
The discussion in this study includes two things. This includes the results of the development of E-marketing based MOOCs products and the integration of e-marketing based MOOCs as a medium in improving the entrepreneurship management of students in the field of vocational education. Discussions related to the results of the development of e-marketing based MOOCs products are the results of the analysis of validation carried out by a team of experts.

\section{E-marketing Synchronization and Consumer Needs}

Based on the results of an analysis of the emarketing expert validation test, it can be concluded that E-marketing based MOOCs products that have been developed entirely successfully. This was indicated by the results of the validation stating that all components of the e-marketing based MOOCs products that were developed were included in the valid category without revision. In addition, the display indicator is neat and systematic, font size selection, and the appearance and presentation of animation validation results enter the category very well. This is in line with the purpose and function of e-marketing that must be able to attract consumers. Some experts explain that e-marketing has a big influence on companies that want to reach consumers more widely and more (Beamish \& Lupton, 2015; Fornaciari et al., 2017). Marketing strategies using internet media can be better known to the wider community. That is because the number of internet users is increasing (Recker \& Mendling, 2016; Udoye \& T, 2017). This system has advantages because it can reach various elements of society so that it will get more consumers. The use of an e-marketing system is useful for creating communication between consumers and producers regarding a product. Therefore, the convenience of consumer interfaces with e-marketing websites must be high. Often this system is useful for conveying criticism or suggestions for products so that the company can improve the quality of its products. The creation of this communication can affect the level of consumers who use or buy the item.

Some experts explain that e-marketing must have a simple level of operation (Aggarwal, 2013; Beamish \& Lupton, 2015). For example, consumers must easily update data related to new products that will come out. In addition, it can also be used as a media transfer database within the company so that it is faster. Conceptually, the use of E-marketing based MOOCs is judged to be easier because it can be run directly without filters that hinder sales. This method does not use a confusing distribution system so that producers can use online media easily. Using an e-marketing based MOOCs system can accelerate widespread sales performance (Heidarinejad, Dalgo, Mattise, \& Srebric, 2018; Strekalova et al., 2018). So that it can accelerate the popularity of a product. Another impact, in this system can display more detailed statistics such as sales, interest rates, price increases, number of products sold and others. So that it can make it easier for companies to survey the needs of the community online media.

The results of the analysis on the website test expert test data explained that the nine indicators tested produced good and very good value. In other words, e-commerce is part of e-marketing where emarketing itself is part of e-business (Hornsby, Messersmith, Rutherford, \& Simmons, 2018; Turner \& Gianiodis, 2018). The concept of personalization is part of the marketing mix contained in need for specific customer identification and identification to build relationships. It is very important to be able to identify company customers (Dahlstedt \& Fejes, 2017; Nabi, Liñan, Fayolle, Krueger, \& Walmsley, 2017).

\section{E-marketing based MOOCs improves entrepreneurial management administration}

The results of the effectiveness test on emarketing products based on MOOCs show that there is a significant difference in the final ability between the experimental classes (using wmarketing based MOOCs) and the control class (not using MOOCs based e-marketing). In learning entrepreneurship courses, students are required to be able to think actively and are good at analyzing market conditions. Through E-marketing based MOOCs products, students can easily interact with customers easily. Also, the level of understanding of students related to all materials in entrepreneurship courses also increased. Students will be able to control all privacy in managing their business administration. Privacy is an element of the marketing mix that is highly related to personalization (Dahlstedt \& Fejes, 2017; Turner \& 
Gianiodis, 2018). When a company collects and stores information about its potential customers, the problem that arises is how and by whom the information is used. The main task that must be done when implementing an internet marketing strategy is to create and develop policies above accessing procedures for information gathering (Andrade et al., 2010; Cheng, Wang, \& Lee, 2018).

The results of this study reveal that using Emarketing based MOOCs improves the entrepreneurial management administration of vocational students. Administration of entrepreneurial management is interpreted as a process of utilizing economic potential creatively, innovatively, and with the courage to face the risk of obtaining useful profits to succeed in programs in educational organizations. So that entrepreneurship can also be said as an element in education to expedite the educational process not as a medium to gain excess profits. Several studies explain that the use of e-marketing as a learning medium has proven effective and able to increase understanding of the entrepreneurial material. Entrepreneurship in the world of education means integrating personalities, opportunities, finances and resources in the surrounding environment in order to take advantage that can be used to succeed in educational goals (Putra, Irdianto, et al., 2016). This personality includes knowledge, skills, attitudes and behavior (Mukhadis et al., 2018). Entrepreneurial souls for education personnel such as heads or managers, expert staff, teachers, employees and other workers by running a business using capital and developing entrepreneurial spirit contain risks (Fox et al., 2018; Gedeon, 2017).

\section{CONCLUSION}

Based on the findings and discussion, it can be concluded as follows. First, the development of e-marketing based MOOCs products have a good percentage of e-marketing expert test results and expert marketing website design tests. In the aspect of ease of accessing consumers, has a validity level of $81.50 \%$, aspects of serving goods/services sold, have a level of validity of $84.10 \%$, a variety of website content variations have a validity level of $79.10 \%$, aspects of conformity with the purpose of the website, has a validity level of $86.00 \%$, the harmony aspect of each page of the display, has a level of validity of $83.70 \%$, the completeness aspect of the description of the product being sold, has a validity level of 83.70 , the attractiveness aspect of emarketing website has a level of validity of $83.70 \%$, aspect ease of order process for consumers, has a validity level of $85.00 \%$, responsive aspects of admin e-marketing, has a validity level of $81.50 \%$, aspects of troubleshooting problems website, has a validity level of $81.50 \%$. Secondly, e-marketing based MOOCs has proven effective in improving the management of entrepreneurial administration for vocational students in the industrial revolution 4.0 era. This was indicated by the results of the final ability test which showed a significant difference between the control class without using emarketing-based MOOCs and the experimental class using MOOCs based e-marketing. Third, emarketing based MOOCs needs to be further developed because it can improve the management of entrepreneurship administration for vocational students in the industrial revolution era 4.0.

\section{REFERENCES}

Abdullah, M. I., Sarfraz, M., \& Kazmi, S. M. H. (2018). Traits of leadership for efficacious communication of Project Management in Software Industry of Pakistan. Khazar Journal of Humanities and Social Sciences, 21(1), 5-22. https://doi.org/10.5782/2223-2621.2018.21.1.5

Aggarwal, M. (2013). The international journal of business \& management Production of Turmeric in India: An Analysis Abstract: The International Journal of Business \& Management, 1(4), 24-36.

Alshanbari, H., \& Issa, R. R. A. (2014). Use of Video Games to Enhance Construction Management Education. Computing in civil and building engineering (CASCE 2014, 2135-2142. https://doi.org/10.1061/9780784413616.053

Andrade, A., Chopra, S., Nurlybayev, B., \& Golab, L. (2010). Quantifying the impact of entrepreneurship on cooperative education job creation. International Journal of WorkIntegrated Learning, 19(1), 51-68. Retrieved from https://www.ijwil.org/files/IJWIL_19_1_51_68. pdf

Arbaugh, J. B., Fornaciari, C. J., \& Hwang, A. (2016). Identifying Research Topic Development in 
Business and Management Education Research Using Legitimation Code Theory. Journal of Management Education, 40(6), 654-691. https://doi.org/10.1177/1052562916631109

Beamish, P. W., \& Lupton, N. C. (2015). Cooperative strategies in international business and management: Reflections on the past 50 years and future directions. Journal of World Business, 163-175. https://doi.org/10.1016/j.jwb.2015.08.013

Bozkurt, A., Akgün-Özbek, E., \& Zawacki-Richter, O. (2017). Trends and Patterns in Massive Open Online Courses: Review and Content Analysis of Research on MOOCs (2008-2015). International Review of Research in Open and Distributed Learning, 18(5), 1-23. https://doi.org/10.19173/irrodl.v18i5.3080

Chawla, V. K., Chanda, A. K., Angra, S., \& Chawla, G. R. (2018). The sustainable project management: A review and future possibilities. Journal of Project Management, 3, 157-170. https://doi.org/10.5267/j.jpm.2017.1.004

Cheng, Y. M., Wang, K., \& Lee, I. K. (2018). Application of engineering education in entrepreneurship construction system. Eurasia Journal of Mathematics, Science and Technology Education, 14(6), 2185-2191. https://doi.org/10.29333/ejmste/86963

Coccia, M. (2017). Economic and Social Thought Disruptive firms and industrial change. Journal of Economic and Social Thought, 4(4), 437-450. Retrieved from http://www.kspjournals.org/index.php/JEST/art icle/viewFile/1511/1499

Dahlstedt, M., \& Fejes, A. (2017). Shaping entrepreneurial citizens: a genealogy of entrepreneurship education in Sweden. Critical Studies in Education, 1-15. https://doi.org/10.1080/17508487.2017.130352 5

Ferasso, M., Pinheiro, I. A., \& Schröeder, C. D. S. (2017). Strategies of innovation in an ancient business: cases of the fountain pen industry. International Journal of Economics and Business Research, 14(1), 73-84. https://doi.org/10.1504/IJEBR.2017.085555

Fornaciari, C. J., Arbaugh, J. B., Asarta, C. J., Bento, R. F., Hwang, A., \& Lund Dean, K. (2017). Key institutions in business and management education research. Decision Sciences Journal
OfInnovative Education, 15(3), 268-302. https://doi.org/10.1080/08832323.2017.133966 0

Fox, J., Pittaway, L., \& Uzuegbunam, I. (2018). Simulations in Entrepreneurship Education: Serious Games and Learning Through Play. Entrepreneurship Education and Pedagogy, $1(1)$, 61-89. https://doi.org/10.1177/2515127417737285

Gedeon, S. A. (2017). Measuring Student Transformation in Entrepreneurship Education Programs. Education Research International, 1-12. https://doi.org/10.1155/2017/8475460

Heidarinejad, M., Dalgo, D. A., Mattise, N. W., \& Srebric, J. (2018). Personalized cooling as an energy efficiency technology for city energy footprint reduction. Journal of Cleaner Production, 171, 491-505. https://doi.org/10.1016/j.jclepro.2017.10.008

Hew, K. F., Qiao, C., \& Tang, Y. (2018). Understanding student engagement in large-scale open online courses: A machine learning facilitated analysis of student's reflections in 18 highly rated MOOCs. International Review of Research in Open and Distance Learning, 19(3), 69-93. https://doi.org/10.19173/irrodl.v19i3.3596

Hornsby, J. S., Messersmith, J., Rutherford, M., \& Simmons, S. (2018). Entrepreneurship Everywhere: Across Campus, Across Communities, and Across Borders. Journal of Small Business Management, 56(1), 4-10. https://doi.org/10.1111/jsbm.12386

Huisman, B., Admiraal, W., Pilli, O., van de Ven, M., \& Saab, N. (2018). Peer assessment in MOOCs: The relationship between peer reviewers' ability and authors' essay performance. British Journal of Educational Technology, 49(1), 101-110. https://doi.org/10.1111/bjet.12520

Imgrund, F., Fischer, M., Janiesch, C., \& Winkelmann, A. (2018). Approaching Digitalization with Business Process Management. Multikonferenz Wirtschaftsinformatik, 1725-1736.

Irdianto, W., \& Putra, A. B. N. R. (2016). The Influence of Education and Economic Background Towards The Training Participants 'Motivation and Study Result of UPT-PK Singosari Malang. In AIP Conference Proceeding (Vol. 1778, pp. 1-7). https://doi.org/10.1063/1.4965795 
Karim, M. S. A. (2016). Entrepreneurship Education in an Engineering Curriculum. Procedia Economics and Finance, 35, 379-387. https://doi.org/10.1016/S2212-5671(16)000472

Kolk, A., \& Rivera-Santos, M. (2018). The State of Research on Africa in Business and Management: Insights From a Systematic Review of Key International Journals. Business \& Society, 57(3), 415-436. https://doi.org/10.1177/0007650316629129

Lambert, S. R., \& Alony, I. (2015). Embedding MOOCs in academic programs as a part of curriculum transformation: A pilot case study. International Conference on Open and Flexible Education, 19.

Mackay, D., \& Zundel, M. (2017). Recovering the divide: a review of strategy and tactics in business and management. International Journal of Management Reviews, 19, 175-194.

Malinova, M., \& Mendling, J. (2018). Identifying do 's and don' ts using the integrated business process management framework. Business Process Management Journal, 24(4), 882-899. https://doi.org/10.1108/BPMJ-10-2016-0214

Mukhadis, A., Putra, A. B. N. R., Nidhom, A. M., Dardiri, A., \& Suswanto, H. (2018). The Relevance of Vocational High School Program With Regional Potency Priority in Indonesia. Journal of Physics: Conference Series, 1028, 1-8.

Nabi, G., Liñan, F., Fayolle, A., Krueger, N., \& Walmsley, A. (2017). The Impact of Entrepreneurship Education in Higher Education: A Systematic Review and Research Agenda. Academy of Management Learning \& Education, $\quad 16(2), \quad 277-299$. https://doi.org/10.5465/amle.2015.0026

Omeno, B. K., \& Sang, P. (2018). Project Management and Performance of Public Sector Construction Projects : A Case of Constituency Development Funds Projects in Migori East ,. International Journal of Current Aspects in Project Management (IJCAPM), I(I), 13-26.

Pardos, Z. A., Tang, S., Davis, D., \& Le, C. V. (2017). Enabling Real-Time Adaptivity in MOOCs with a Personalized Next-Step Recommendation Framework. Engineering Learning Environments, $\quad 1(1), \quad 23-32$. https://doi.org/10.1145/3051457.3051471
Putra, A. B. N. R., Irdianto, W., \& Mukhadis, A. (2016). Pocket Book Learning: Learning Methods to Train Students Productive and Creative using ‘ BRANO' as an Effective Learning Recorder. In AIP Conference Proceeding (Vol. 1778, pp. 17). https://doi.org/10.1063/1.4965768

Putra, A. B. N. R., Mukhadis, A., Partono, P., Nauri, I. M., Purwanto, E. E., \& Sholah, A. (2018). Inovasi pembelajaran mutakhir dengan mind mapping dalam upaya meningkatkan kompetensi expert dan akselerasi pola pikir mahasiswa. Jurnal Teknik Otomotif Kajian Keilmuan Dan Pengajaran, 1(1), 8-15. (In Indonesian)

Putra, A. B. N. R., Mukhadis, A., \& Suhartadi, S. (2016). Miskonsepsi Transmisi Mobil dan Pemecahannya Menggunakan Pembelajaran Peta Pikiran pada Kompetensi Memelihara Transmisi Mobil Siswa SMK. Teknologi Dan Kejuruan, 38(2), 133-146. (In Indonesian)

Rahimi, F., Møller, C., \& Hvam, L. (2016). Business process management and IT management: The missing integration. International Journal of Information Management, 36(1), 142-154. https://doi.org/10.1016/j.ijinfomgt.2015.10.004

Recker, J., \& Mendling, J. (2016). The State-of-the-Art of Business Process Management Research as Published in the BPM conference: Recommendations for Progressing the Field. Business \& Information Systems Engineering, 58(1), 55-72.

Saggaf, M. S., Salam, R., Wirawan, H., \& Hasanuddin, U. (2018). The Influence of Teacher's Pedagogic Competence on Learning Motivation of Student of Office Administration Expertise Package. In 8th International Conference of Asian Association of Indigenous and Cultural Psychology (Vol. 127, pp. 111-114).

Sousa, M. J., \& Rocha, Á. (2018). Skills for disruptive digital business. Journal of Business Research, $1(1)$, $1-7$. https://doi.org/10.1016/j.jbusres.2017.12.051

Strekalova, Y. A., Karimipour, N., James, V., \& Treise, D. (2018). Assessing Risk Perceptions of ESmoking Devices: a Cross-Sectional Consumer Survey. The Journal of Behavioral Health Services \& Research. https://doi.org/10.1007/s11414-018-9594-y

Torabi, S. A., Giahi, R., \& Sahebjamnia, N. (2016). An enhanced risk assessment framework for 
business continuity management systems. Safety Science, $\quad$ 201-218. https://doi.org/10.1016/j.ssci.2016.06.015

Turner, T., \& Gianiodis, P. (2018). Entrepreneurship Unleashed: Understanding Entrepreneurial Education outside of the Business School. Journal of Small Business Management, 56(1), 131-149. https://doi.org/10.1111/jsbm. 12365

Udoye, R. N., \& T, M. P. (2017). Strategies to promote entrepreneurship educationamong tertiary education students in delta state. Nigerian Journal of Business Education, 4(2), 124-130.
Wu, B., \& Chen, X. (2017). Continuance intention to use MOOCs: Integrating the technology acceptance model (TAM) and task technology fit (TTF) model. Computers in Human Behavior, 67, 221232. https://doi.org/10.1016/j.chb.2016.10.028

Zancanaro, A., Nunes, C., \& Domingues, M. (2017). Evaluation of Free Platforms for Delivery of Massive Open Online Courses (MOOCS). Turkish Online Journal of Distance Education, 18(1), 166-181. Retrieved from https://eric.ed.gov/?id=EJ1124969. 